Original Paper

\title{
Relationship between Feedstock Price and Break-Even Point of Woody Biomass Power Generation under FIT Program
}

\author{
Takashi YanagidA, Takahiro YoshidA, Hirofumi KuBOYAmA, and Masaki JinkAWA \\ (Received August 19, 2014) \\ 再生可能エネルギー固定価格買取制度を利用した木質バイオマス発電事業における \\ 原料調達価格と損益分岐点の関係 \\ 柳田高志，吉田貴紘，久保山裕史，陣川雅樹
}

\begin{abstract}
In July 2012, the Government of Japan introduced the "Feed-in Tariff (FIT) Program for Renewable Energy Use". Currently, quite a few woody biomass power plants are under construction in various regions to take advantage of the FIT program. Unutilized forest biomass is expected to use for the fuel in the biomass power generation. However the supply cost, including cutting and transportation costs, of unutilized forest biomass is varied from the geological condition. Decision of the target supply cost depends on the transaction price of biomass at the power plant. The purpose of this study is to provide an information of feedstock cost on brake-even point of the biomass power generation. Electricity production cost of biomass power generation is estimated by establishment of cost estimation model. The feedstock cost on break-even point of biomass power generation in the scale range of $500-20,000 \mathrm{~kW}$ is estimated. These values may help the decision of the target supply cost of the biomass in the forest sector.
\end{abstract}

2012 年 7 月に再生可能エネルギー固定価格買取制度が施行され, 各地に木質バイオマス発電所の計画が相次いでおり, 今後, 燃料となる間伐材や林地残材の利用促進が期待されている。しかしながら, 間伐材や林地残材の搬出は地域差や 条件により費用が大きく異なるため, 発電所の原料受入価格の目安を基に供給費用の目標值を設定し, 搬出の可否を判断 するのが望ましい。そこで, 本研究では, 森林に拈ける間伐材や林地残材等の未利用木質バイオマスの供給コストの目標 值設定に資する情報を提供することを目的とする。まず， $500 \mathrm{~kW} \sim 20,000 \mathrm{~kW}$ 規模のバイオマス発電を対象に，内閣官房 国家戦略室コス卜等検証委員会の発電コスト試算シートをベースにしたモデルを作成し，バイオマス発電に関するデー夕を組 み込み，発電コス卜等の試算検討を行った。その上で，発電規模，原料含水率を変数としたときの発電事業の損益分岐点 上にある原料コストを整理した。森林の未利用バイオマスの供給コストに関する限界の指標の一つを提示できたと考える。

Key Words

Forest biomass, Power generation, FIT, Supply cost, Break-even point

\section{1. はじめに}

国内では 2012 年 7 月に再生可能エネルギー固定価格買取 制度 (Feed-In Tariff, FIT) が施行して 2 年が経過した。その FITにおける買取価格 ${ }^{1)}$ は，木質系バイオマスを 4 種類に分 類しており (Table 1)，その中でも特に間伐材等の未利用木

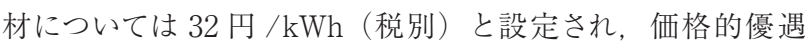
策がとられている。これによって, 現在供給コストの問題を 抱えている間伐材や林地残材の利用促進が期待されている。

Forest and Forestry Products Research Institute

1 Matsunosato, Tsukuba, Ibaraki 305-8687, Japan
事実, 日本各地に木質バイオマス発電所の計画が相次いで おり，資源エネルギー庁の公表資料 ${ }^{1)}$ によると，2014 年 3 月までに認定された木質バイオマス発電 (「一般廃革物, そ の他のバイオマス」は除く）は全国で 60 件 (計 126 万 $\mathrm{kW}$ ) に上る。稼働中の発電所 ${ }^{11}$ は, “間伐材等由来の木質バイオマ ス”拈よび“一般木質バイオマス”に分類される発電所は 5 件 あり, 福島県 $5,700 \mathrm{~kW}$, 栃木県 $265 \mathrm{~kW}$, 長野県 $1,500 \mathrm{~kW}$, 大分県 $5,700 \mathrm{~kW}$, 高知県 $29,500 \mathrm{~kW}$ である。これら以外 
Table 1 Electricity price in feed-in tariff for woody biomass

\begin{tabular}{lc}
\hline \multicolumn{1}{c}{ Classification } & Price[JPY/kWh] \\
\hline Unutilized forest biomass & \\
(ex. Thinned wood, forest residue) & 32 \\
General wood (ex. saw mill residue, PKS) & 24 \\
Demolition wood & 13 \\
Waste (ex. pruned branch) & 17 \\
\hline
\end{tabular}

の現在までに稼働している発電所は岩手県 $5,700 \mathrm{~kW}{ }^{2)}$ が挙 げられ，以上の稼働している発電所の合計出力は 5 万 $\mathrm{kW}$ 以下と少ない。このように, 現状として, 未利用バイオマス を活用する発電所の稼働状況はまだわずか 3) 4)ではあるが, 2015 年末までに多数のバイオマス発電が新たに稼働するこ とが予想されている。計画中の木質バイオマス発電は, 約 4 割が $5,000 \sim 10,000 \mathrm{~kW}$ 規模で，その多くが未利用木材を 然料とすることを想定している3)。このような状況下で, 建 設計画が集中している地域では, 原料の調達範囲の競合な どから原料の安定供給とその価格安定性が不安視されてお り，どのように既存のチップ消費者および新設発電所間で原 料面の共存を図っていくかが課題となっている4)。一方，未 利用バイオマスの供給側は，これまで採算が合わずに搬出 できなかった間伐材や林地残材の受け㿼ができたことで，搬 出の準備を始めており，木材破砕機やチップ製造機を購入 し供給体制を整えつつある5)。ただし，発電サイトでの原料 受入価格に上限があるのも事実であり, 未利用バイオマス の搬出からチップ製造に掛ける費用がこの価格を下回ること が前提となることから， ある程度の目標值を設定して供給体 制を整えることが望ましい。しかしながら，このバイオマス 原料の価格には注意が必要である。未利用バイオマスを原 料とした木質バイオマス発電のサプライチェーンにおける取 引単位は異なっており（Fig. 1)，特に，木質チップの取引で は同じ質量のバイオマスでも含水率の違いにより価格が異な る。なぜなら, 生材由来の木質チップは水を多く含んでいる ので, 乾燥の度合いによって単位重量当たりの発熱量が大き く異なるからである。このように発電サイトへの供給段階に おいて熱量的に不安定な品質の木質バイオマスの規格の統 一化は図られて扔らず，発電事業者が個別に対応しているの が現状であり, バイオマスの供給側にとっても価格がわかり
にくいものになっている。そのため, 原料供給側から搬出コ ストの目安に関する要望が挙げられている。その一例 6)を挙 げると,「木質バイオマス発電所の収益と収支の概算金額が 把握できる早見表や, チップや原木の受入価格を逆算試算 できるマニュアル等の整備」等がある。これまで, バイオマ ス発電に関する研究は数多〈報告 7) 14) されているが，木質 バイオマス発電の損益分岐点上にある原料価格について整 理した報告はされていない。損益分岐点上にある原料価格 は，原木の調達コストの目安を算定する指標となり得ると考 えられる。これらの問題を解決するためには, 上述のように, 未利用木質バイオマスの含水率と発電コストの関係について の整理が不可欠である。そこで, 本研究では, 森林におけ る未利用木質バイオマスの搬出量と供給コストの目標值設定 に資するための，原料含水率を考慮した基礎情報を提供す ることを目的として，木質バイオマスの価格と発電コストにつ いて検討する。まず, $500 \mathrm{~kW} \sim 20,000 \mathrm{~kW}$ 規模のバイオマ ス発電事業に扔いて原料含水率の違いを考慮した原料消費 量を整理し，それを基に原料価格を固定したときの発電規 模の違いを考慮した発電コス卜試算を行う。また, 原料価 格を変動させ, 事業の収入と支出が均衡して利益のない状 態の点, すなわち損益分岐点を明らかにすることは極めて重 要である。なぜなら, 原料価格の上昇に伴い, 損益分岐点 から支出増加側の領域に移行した場合, 発電事業が困難に なるからである。そこで, 本研究では, 発電事業の損益分 岐点上にある原料価格を明らかにすることを目的とする。

\section{2. 未利用木質バイオマスを用いた木質バイオマス発電システム}

本研究で検討する発電システムの境界領域は, 燃料とし ての木質チップの受け入れから系統への電力供給までとする (Fig. 2)。木質チップの原料は未利用木質バイオマスとして 間伐材と林地残材を想定する。発電は, 木質チップをボイラー に供給し, 蒸気を発生させ, その蒸気でタービンを回転さ せ, 発電する方式を想定する。ここで生産される発電量を総 発電量 $($ Egross $)$ とし, この発電出力の大きさを発電規模と 定義する。この総発電量から所内率分 (Eauxi) を差し引い たものを正味発電量 (Enet) とし，このEnet 全量を系統に供 給し売電する。木質チップに含まれる灰はボイラーから回収 され廃棄処理される。実際の発電では, FIT上で買取価格

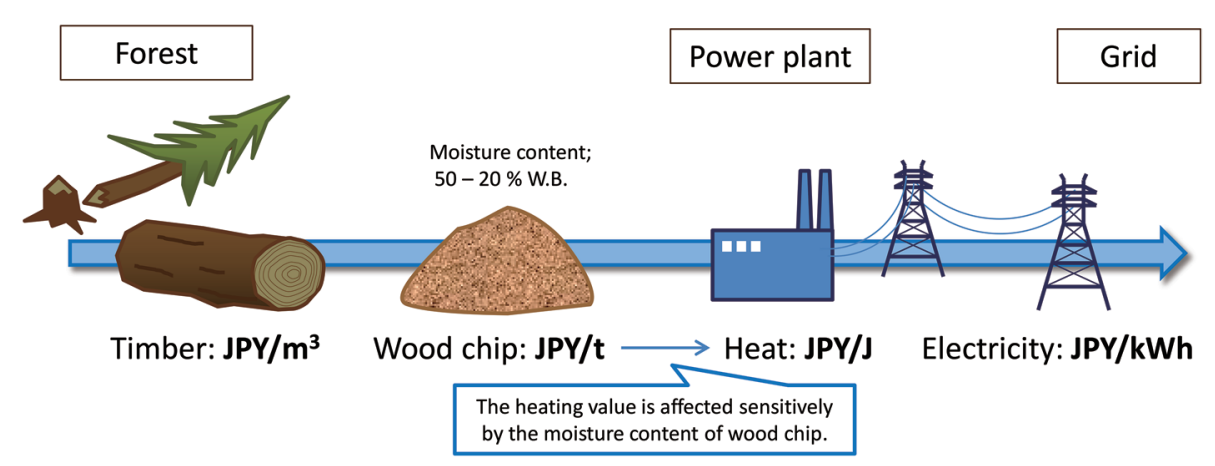

Fig. 1 The difference of trading unit on the supply chain of biomass power generation 


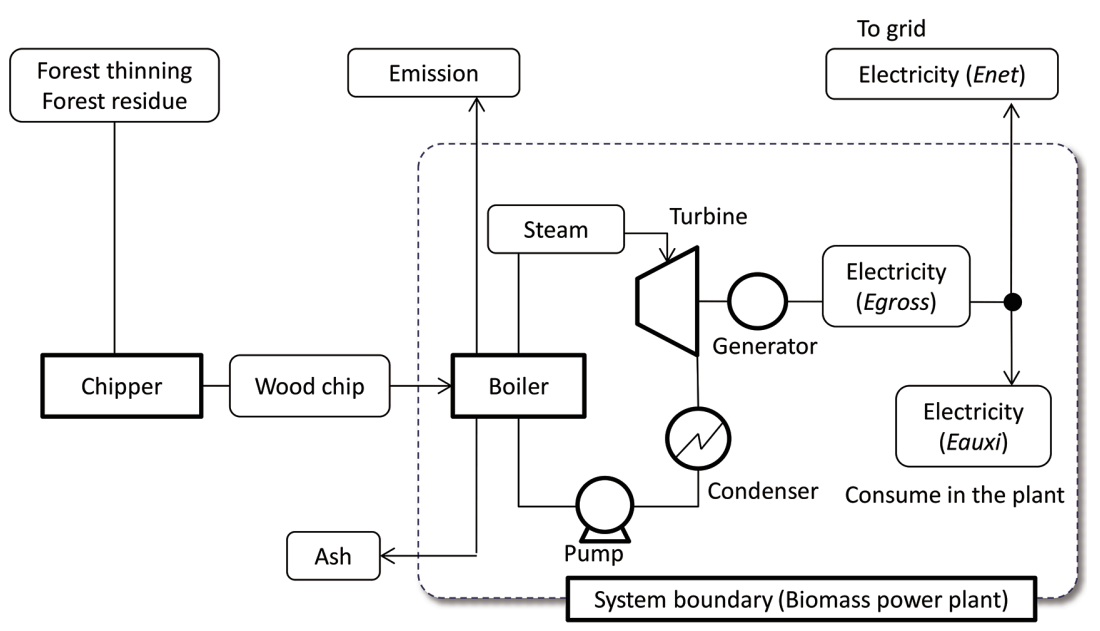

Fig. 2 System flow diagram of biomass power generation using unutilized forest biomass

の異なる原料を組み合わせて燃料とするケースもある2)。他 方，発電のシステムも排熱を有効に利用する熱電併給が事業

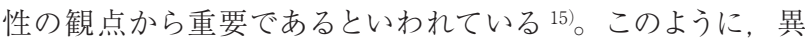
なる燃料の組合せやシステムも想定されるが，それらについ ては今後の課題とし, 本研究では, 未利用木質バイオマスを 用いて電気のみを生産するシステムについて検討する。

\section{3. プロセスの基本データ}

\section{1 燃料 (木質チップ) の組成}

実際のバイオマス発電は，樹種や部位の異なる原料が使 用されると考えられ，それらの化学組成は異なる。しかし ながら，熱化学変換である燃焼においては，元素組成や発 熱量が重要であり, それらは比較的均一である。ここでは, 木質バイオマスの高位発熱量を $18 \mathrm{MJ} / \mathrm{kg}$, 灰分率を $1.0 \%$ と 仮定した。ただし，燃料に含まれる水分に大きく影響される 低位発熱量は発電コストに対して影響力の高い要因となるの で，ここではベースケースとしての值を設定し，4.3 節の感度 分析でばらつきの影響について検証する。ベースケースの值 は, 燃料に含まれる含水率 (湿潤基準 Wet basis: W.B., 以下,
含水率は W.B. とする) を $40 \%$ と設定し, 高位発熱量から式 （1）16）用いて低位発熱量に変換した。

$\mathrm{LHV}=\mathrm{HHV} \cdot(1-\mathrm{MC} / 100)$

$-2.443 \cdot(9 \cdot \mathrm{HC} / 100 \cdot(1-\mathrm{MC} / 100)+\mathrm{MC} / 100)$

ここで，LHV，HHV，MC，HCは，それぞれ燃料の低位 発熱量 $[\mathrm{MJ} / \mathrm{kg}]$, 高位発熱量 $[\mathrm{MJ} / \mathrm{kg}]$, 含水率 $[\%]$ およ び水素含有率 [\%] である。水素含有率は $6 \%$ と仮定した。

\section{2 発電効率, 所内率}

木質バイオマス発電に拀いて, 発電効率は発電規模と強 い相関がある。本研究では，木質バイオマス発電に関すると アリングおよび文献 17) 18) からデー夕を収集し（Table 2, Fig. 3), 発電規模と発電端効率 (以下, 発電効率とする) の相 関関係式 (2) を導出した。

$\eta=5.762 \ln (P S)-26.65 \mathrm{R}^{2}=0.93$

ここでの， $\eta, P S$ はそれぞれ発電効率および発電規模であ る。発電効率 $\eta$ は投入したバイオマスのエネルギー量に対し て得られた電気のエネルギー量の割合で,この式中での単 位は\%である。発電規模 $P S$ の単位は $\mathrm{kW}$ である。

Table 2 Data list of woody biomass power generation plant

\begin{tabular}{l|c|c|c|c}
\hline Power plant (location) & Plant scale; $\mathrm{kW}$ & $\begin{array}{c}\text { Power generation } \\
\text { efficiency; } \%\end{array}$ & $\begin{array}{c}\text { Auxiliary power ratio ; } \\
\mathrm{kW} / \mathrm{kW}\end{array}$ & Construction year \\
\hline A (Fukushima) & 11,500 & 27 & & 2006 \\
\hline B (Ibaraki) & 4,900 & 22.47 & & 2005 \\
\hline C (Niigata) & 50,000 & 35 & & 2005 \\
\hline D (Toyama) & 990 & 12.1 & & 2007 \\
\hline E (Gifu) & 600 & 11.2 & 0.12 & 1985 \\
\hline F (Hiroshima) & 2,000 & 12.5 & 0.15 & 2006 \\
\hline G (Yamaguchi) & 10,000 & 29 & 0.13 & 2006 \\
\hline H (Oita) & 12,000 & 27 & 0.15 & 2012 \\
\hline I (Fukushima) & 5,700 & 26 & 0.18 & \\
\hline J (Nagano) & 1,300 & 16 & 0.12 & \\
\hline K: manufacture's data & 3,550 & 20 & 0.10 & \\
\hline L: manufacture's data & 6,250 & 28 & & \\
\hline N: manufacture's data & 20,000 & & & \\
\hline
\end{tabular}




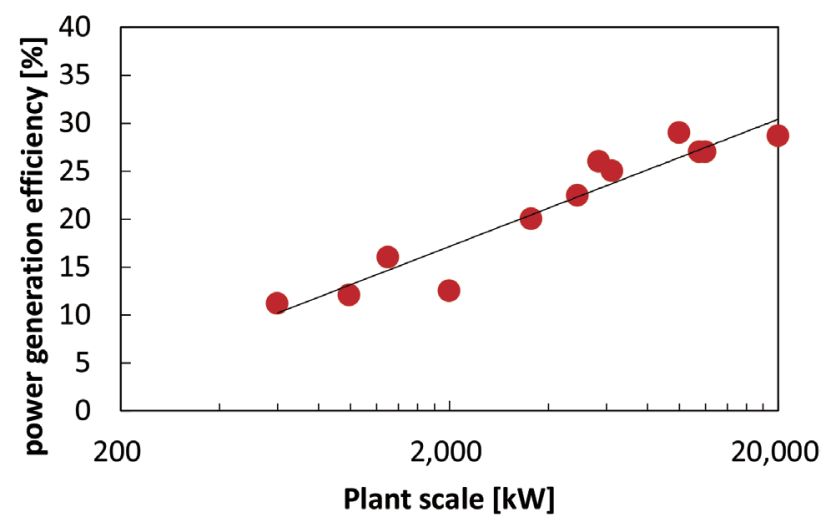

Fig. 3 Power generation efficiency of biomass power plant

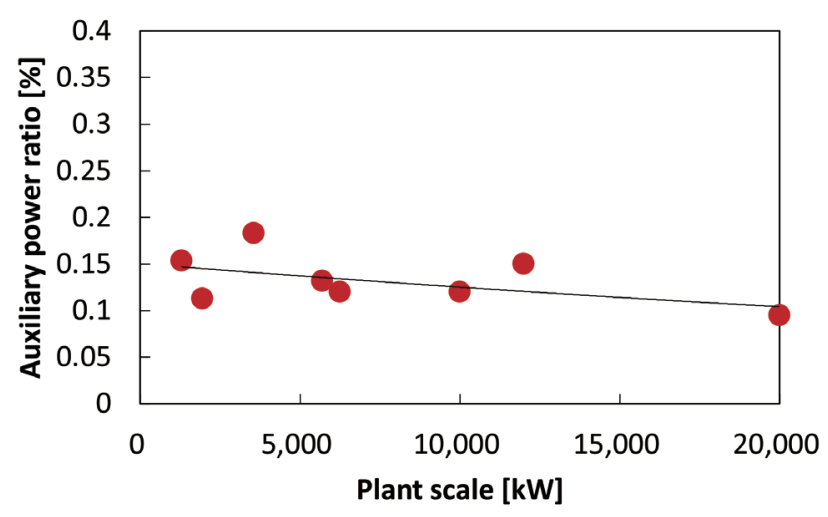

Fig. 4 The auxiliary power ratio of biomass power plant

所内率についても，ヒアリングおよび文献值 17) 18) から発 電規模と所内率の関係を整理（Table 2, Fig. 4) し，相関式 (3) を導出した。

$$
A P=0.1505 \exp \left(-1.841 \cdot 10^{-5} \cdot P S\right) \quad \mathrm{R}^{2}=0.31
$$

ここでの, $A P, P S$ はそれぞれ所内率および発電規模であ る。は所内率 $A P$ は発電した電力のうち発電所内の設備で 消費される電力量の割合で，この式中での単位は\%である。 発電規模 $P S$ の単位は $\mathrm{kW}$ である。

\section{4. コストの試算方法と前提条件}

国内のバイオマス発電プラントの規模は $500 ＼mathrm{~ 50,000 ~ k W ~}$ と様々であり，そのうち 5,000～10,000 kW の規模が約 4 割を占める ${ }^{3)}$ 。最大規模の $75,000 \mathrm{~kW}$ になると，燃料は未 利用木質バイオマスの他に海外からのパーム椰子殼 (Palm kernel Shell : PKS) や石炭を混合する方式になる ${ }^{19)}$ 。未利 用木質バイオマスのみを燃料とする発電プラントは, 燃料 供給量が制限要因となり, 発電出力 $20,000 \mathrm{~kW}$ 以上の大規 模発電は見当たらない。本研究では, 未利用木質バイオマ 久専焼発電について検討する目的から，発電規模を500 20,000 kW の範囲に設定した。発電プラントの建設費につい ては，ヒアリングおよび文献值 ${ }^{17)}$ 18) から発電規模と建設費 の関係を整理 (Fig. 5) し，相関式 (4) を導出した。

$P C=0.0835 \cdot(P S) 0.6763 \quad \mathrm{R}^{2}=0.89$

ここでの, $P C, P S$ はそれぞれプラント建設費および発電規 模である。プラント建設費 $P C$ の単位は億円, 規模 $P S$ の単

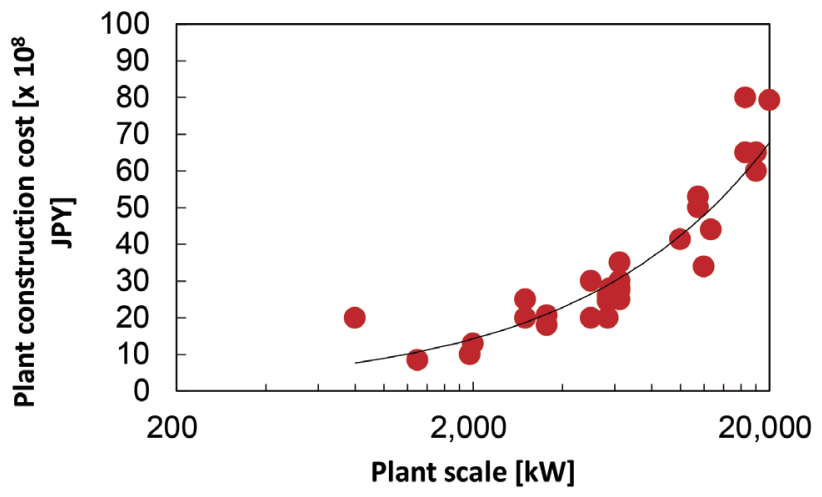

Fig. 5 Construction cost of biomass power plant

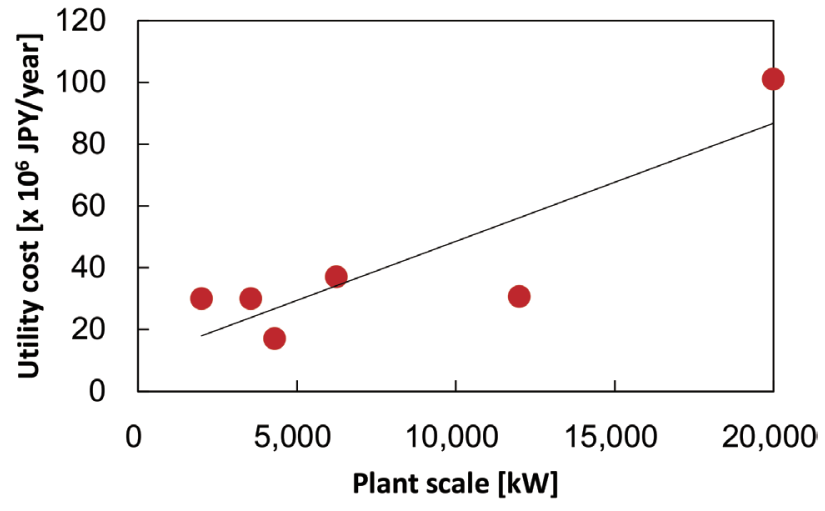

Fig. 6 Utility cost of biomass power plant

位は $\mathrm{kW}$ である。

発電に使用する薬品や水道等に関する費用をユーティリ ティ費とし, ヒアリングから得られたデータ（Fig. 6) を整理し, 推算式 (5) を導出した。

$$
\mathrm{I}=3,823 \cdot(P S)+10,281,107 \quad \mathrm{R}^{2}=0.75
$$

ここでのI, $P S$ はそれぞれユーティリティ費および発電規 模である。ユーティリティ費 I は年間あたりの費用で単位は 円/年である。発電規模の単位は $\mathrm{kW}$ である。

発電コストは, 発電事業に関わる総費用を発電電力量で 除して求めた。発電コストの試算式を式 (6)に示す。

$\mathrm{EPC}[\mathrm{JPY} / \mathrm{kWh}]$

$$
\begin{aligned}
= & \sum_{i=1}^{n}\left(\mathrm{~A}_{i}+\mathrm{B}_{i}+\mathrm{C}_{i}+\mathrm{D}_{i}+\mathrm{E}_{i}+\mathrm{F}_{i}+\mathrm{G}_{i}+\mathrm{H}_{i}+\mathrm{I}_{i}\right. \\
& \left.+\mathrm{J}_{i}\right) / \sum_{i=1}^{n} K_{i}
\end{aligned}
$$

ここでの $\mathrm{EPC}, \mathrm{A}, \mathrm{B}, \mathrm{C}, \mathrm{D}, \mathrm{E}, \mathrm{F}, \mathrm{G}, \mathrm{H}, \mathrm{I}, \mathrm{J}$, お よび $\mathrm{K} は$ は, それぞれ発電コス卜, 燃料費, 減価償却費, 固 定資産税, 人件費, 保守 - 点検費, 保険費, 一般管理費, 灰処理費，ユーテイリテイ費，利子返済費抢よび発電量であ る。

本研究における発電コストの試算は, 内閣官房国家戦略 室コスト等検証委員会の発電コスト試算シート 20)をベースに, 上記の式（1-5）の組み込み, ならびに,一般管理費, 保険費, 灰処理費，ユーティリテイ費，借入金利子返済費の項目を追 加する方法で行った。各項目の試算方法ならびに設定条件 を Table 3 に示す。発電事業のプロジェクト期間は, FITで の買取期間を想定し，20 年間とした。なお，式（6）における 
Table 3 Cost component of electricity production cost

\begin{tabular}{|c|c|c|}
\hline & Cost component & Factor and setting conditions \\
\hline EPC & Electricity production cost & $\sum_{i=1}^{n}\left(\mathrm{~A}_{i}+\mathrm{B}_{i}+\mathrm{C}_{i}+\mathrm{D}_{i}+\mathrm{E}_{i}+\mathrm{F}_{i}+\mathrm{G}_{i}+\mathrm{H}_{i}+\mathrm{I}_{i}+\mathrm{J}_{i}\right) / \sum_{i=1}^{n} K_{i}$ \\
\hline $\mathrm{A}_{i}$ & Feedstock cost [JPY/year] & $\mathrm{A}=F C \cdot F P$ \\
\hline $\mathrm{Bi}$ & Depreciation cost [JPY/year] & $\mathrm{B}=(P C / D P)$ \\
\hline $\mathrm{C}_{i}$ & $\begin{array}{l}\text { Fixed property tax cost for plant [JPY/year] } \\
\text { (Amounts are rounded down to the nearest } 100 \mathrm{JPY} \text { ) }\end{array}$ & $\mathrm{C}=R V \cdot F T / 100$ \\
\hline $\mathrm{D}_{i}$ & Labor cost [JPY/year] & $\mathrm{D}=O P \cdot L F$ \\
\hline $\mathrm{E}_{i}$ & Maintenance cost [JPY/year] & $\mathrm{E}=P C \cdot 0.03$ \\
\hline $\mathrm{F}_{i}$ & Insurance cost [JPY/year] & $\mathrm{F}=P C \cdot 0.004$ \\
\hline $\mathrm{G}_{i}$ & General administrative cost [JPY/year] & $\mathrm{G}=\mathrm{D} \cdot 0.25$ \\
\hline $\mathrm{H}_{i}$ & Ash disposal cost [JPY/year] & $\mathrm{H}=A G \cdot A F$ \\
\hline $\mathrm{I}_{i}$ & Utility cost [JPY/year] & $\mathrm{I}=3,823 \cdot(P S)+10,281,107$ eq.(5), Fig. 6 \\
\hline $\mathrm{J}_{i}$ & Repayment of debt [JPY/year] & $\mathrm{J}=((P C-(P C / R P) \cdot(n-1)) \cdot(r / 100))$ \\
\hline $\mathrm{K}_{i}$ & Electricity production amount [JPY/year] & $\mathrm{J}=P S \cdot(1-A P / 100) \cdot O H$ \\
\hline$n_{p}$ & Project period [years] & 20 years as purchase period on FIT program \\
\hline$P S$ & Plant scale (generating-end output) $[\mathrm{kW}]$ & Range from 500 to $20,000 \mathrm{~kW}$ \\
\hline$P C$ & Plant construction cost $\left[\mathrm{x} 10^{8} \mathrm{JPY}\right]$ & $P C=0.0835 \cdot(P S) 0.6763 \quad$ eq.(4), Fig. 5 \\
\hline$D P$ & Depreciation period [years] & 15 years \\
\hline$R P$ & Repayment period & 15 years repayment with principal equal method \\
\hline$r$ & Interest [\%] & 3 \\
\hline$\eta$ & $\begin{array}{l}\text { Power generation efficiency (generating-end output, LHV } \\
\text { basis) [\%] }\end{array}$ & $\eta=5.762 \ln (P S)-26.65$ eq.(2), Fig. 3 \\
\hline$A P$ & Auxiliary power ratio [\%] & $A P=0.1505 \exp \left(-1.841 \cdot 10^{-5} \cdot P S\right)$ eq.(3), Fig. 4 \\
\hline Enet & Net electricity generation [\%] & Enet $=P S \cdot(1-A P)$ \\
\hline $\mathrm{OH}$ & Annual operating hours [hours/year] & 330 [days/year] $\cdot 24$ [hours/day] $=7,920$ \\
\hline$L H V$ & LHV of feedstock $[\mathrm{MJ} / \mathrm{kg}]$ & $\begin{array}{l}L H V=H H V \cdot(1-M C / 100)-2.443 \cdot(9 \cdot H C / 100 \cdot(1-M C / 100)+ \\
M C / 100)\end{array}$ \\
\hline$H H V$ & HHV of feedstock $[\mathrm{MJ} / \mathrm{kg}]$ & 18 \\
\hline$M C$ & Moisture content of feedstock [\%, wet basis] & Range from 20 to 50 \\
\hline$H C$ & Hydrogen content of feedstock [\%, dry basis] & 6 \\
\hline$A C$ & Ash content of feedstock [\%, dry basis] & 1 \\
\hline$F C$ & Feedstock consumption [tons/year] & $F C=(P S \cdot O H \cdot 3.6[\mathrm{MJ} / \mathrm{kWh}]) /(\eta / 100) / L H V / 1,000$ \\
\hline$F P$ & Feedstock price [JPY/ton] & 12,000 (as base case) \\
\hline UT & Statutory useful time [years] & 15 years \\
\hline$F T$ & Fixed property tax rate [\%] & 1.4 \\
\hline$R V$ & $\begin{array}{l}\text { Ratable value [JPY] } \\
\text { (Amounts are rounded down to the nearest 1,000 JPY) }\end{array}$ & $\begin{array}{l}\text { Previous year's } R V \cdot(1-D R) \\
\left({ }^{*} \text { Only first year of the project: PC } \cdot(1-D R / 2)\right)\end{array}$ \\
\hline$D R$ & Depreciation rate & 0.142 as $U T$ is 15 years \\
\hline$O P$ & Number of operators [person] ${ }^{21}$ & $\begin{array}{l}\text { Range from } 200 \text { to } 1,000 \mathrm{~kW}: O P_{200-1,000 \mathrm{~kW}}=0.005 \text { Enet } \\
\text { Range from } 1,000 \text { to } 10,000 \mathrm{~kW}: O P_{1,000-10,000 \mathrm{~kW}}=0.000778 \mathrm{Enet}+ \\
4.222 \\
\text { Range from } 10,000 \text { to } 20,000 \mathrm{~kW}: O P_{10,000-20,000 \mathrm{~kW}}=12\end{array}$ \\
\hline$L F$ & Labor fee [JPY/person/year] & $5,000,000$ \\
\hline$A G$ & Ash generation amount [tons/year] & $A G=F C \cdot(1-(M C / 100)) \cdot(A C / 100)$ \\
\hline$A F$ & Ash disposal fee [JPY/ton] & 20,000 \\
\hline
\end{tabular}

発電電力量は Fig. 2 における正味発電量 $($ Enet $)$ である。プ ラントの建設費は全額借り入れると仮定し, 補助金はなしと した。この建設費は, 法廷耐用年数で減価償却すると仮定し, その費用を減価償却費とした。借入返済に係わる利息分を 金利返済費として計上した。人件費は，運転要員数とその単 価の積で算出しているが, 運転要員数は報告書 21$)$ で提案さ れている算出式を用いて試算した。運転要員以外の人件費 は，一般管理費に組み込むこととした。木質バイオマスの燃
焼に伴い発生する灰の処理費用として，20,000 円/tを想定 した。

\section{5. 結果と考察}

\section{1 バイオマス発電に必要な木質バイオマス量}

木質バイオマス発電の燃料必要量を Table 3 の FC の式を 用いて試算した。結果を Fig. 7 に示す。たとえば, 5,000 kW 規模の場合, 含水率 40\%の木質バイオマスを燃料とすると, 


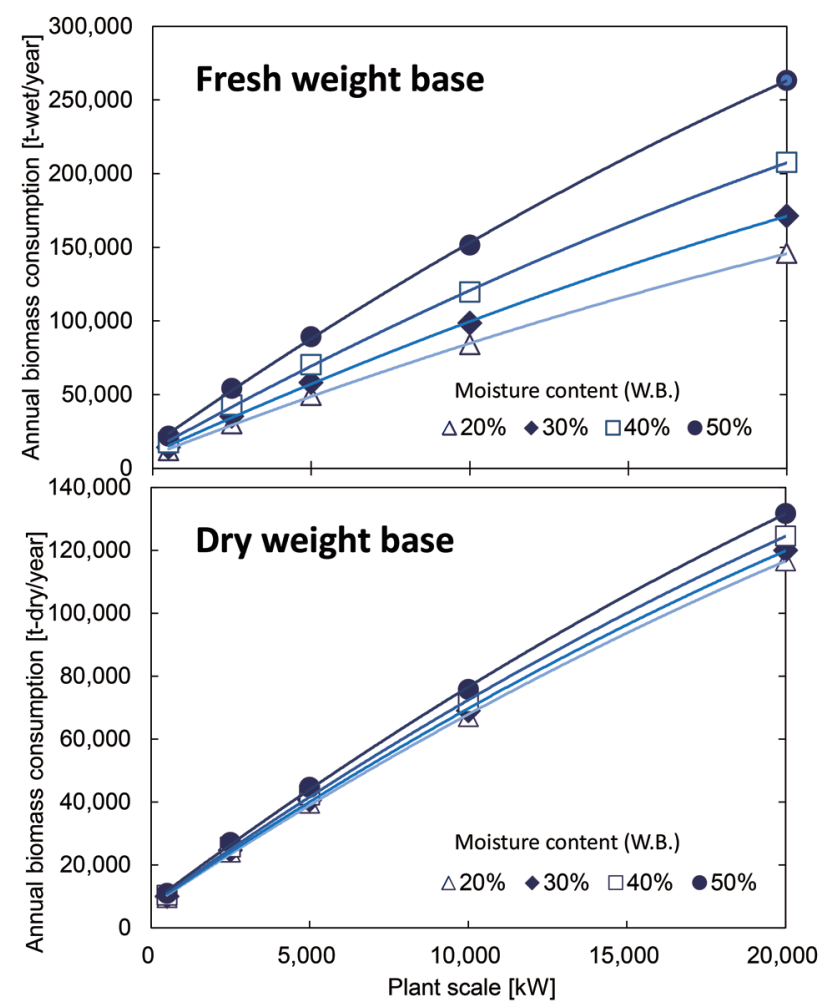

Fig. 7 Annual biomass consumption at biomass power plant

年間に必要なバイオマスは約 7.0 万 t-wet と推計される。森 林の原木丸太消費量は, 実際の発電所で用いられるバイ オマスの樹種や産地の違い, 含水率による誤差があるため 精確な推計は難しいが, 全乾重量と全乾密度 (スギ $0.40 \mathrm{~g}$ / $\mathrm{cm}^{3}$ を用いた $\left.{ }^{22)}\right)$ から原木丸太の材積を試算すると, 約 10.5 万 $\mathrm{m}^{3}$ となる。この消費量は県単位の素材生産量に匹敵する 量である。平成 24 年木材需給報告書 ${ }^{23)}$ によると, 新潟県, 石川県, 福井県, 愛知県, 佐賀県, 長崎県の素材生産量が それぞれ約 9 〜 13 万 $\mathrm{m}^{3}$ であることから，バイオマス発電 が地域の林業に与える影響の大きさが実感できる。FIT は 20 年間の買取保証であるため, バイオマス発電プラントの設 置にあたっては 20 年以上にわたって原料を安定供給する持 続性を担保しなければならない。そのため, バイオマス発電 が過密な地域では原料の使用量を減らす工夫も重要である。 Fig. 7 より, 原料の含水率の違いは, 原木の消費量に大き く影響する。たとえば，含水率 $50 \%$ の原料を $30 \%$ まで乾燥 させてからボイラーで燃焼させることで, 森林の原木消費は 約 1 割削減できる。バイオマスの低コスト乾燥化技術はその ための重要な鍵となるであろう。

\section{2 発電コスト}

木質バイオマス発電の原料としての未利用バイオマスは, 間伐材や林地残材などの種類があり, 山林の地形や搬出 システムの違いにより搬出コストが様々である。ここではそ の作業コストの一例を示す。Kamimura ら ${ }^{24)}$ は, 間伐材の チップ化におけるプロセスコストとして, 作業道までの木寄 せ，搬出，チップ加工をそれぞれ 4,286，3,660，3,532 円／ t-wet としている。これらに輸送費を上乗せすると, 間伐材 を伐採して発電サイトまで輸送したときの木質チップの価格, すなわち発電サイトにおける原料コストは，少なく見積もっ ても約 12,000 円/t-wet と推定される。これは, 調達価格等 算定委員会の報告書 ${ }^{3)}$ の価格と同水準になっている。そこ で，原料価格を 12,000 円/t-wet，および，その前後として， それぞれ10,000 円/t-wetと14,000 円/t-wetとした場合の 発電コストを試算した。なお，ここでの原料含水率は $40 \%$ と仮定した。Fig. 8 に試算結果を示す。発電コス卜は発電規 模が大きくなるにつれ低減され, いわゆる規模の経済が顕 著に現れている。本検討の未利用木質バイオマスの電力買 取価格は 32 円 / kWh なので, 発電コストがこの価格を下回 る場合に採算がとれることになる。バイオマス発電は発電規 模 5,000 kW 以上でないと採算がとれないといわれており ${ }^{25)}$, 本検討では発電コストの項目を増やして試算しているため に, その追加分が増加しているが, 同水準の結果が得られた。 小規模な発電は, 発電コストが売電コストを上回ってしまい, たとえば, $500 \mathrm{~kW}$ 規模の発電コストは，売電価格 32 円 /kWhの 2.4〜3.1倍となった。小規模で事業をおこなうには, 格安で燃料が入手出来るルートを確保することや, 熱利用等 の副次的な収入源が必要と思われる。

発電コストの内訳について, それぞれの項目が占める割合 を Table 4 に示す。原料費は発電コストの約 6 割以上を占め ており, 最も大きな要因である。原料費は原料調達価格と原 料消費量の積で構成されているので, これらに関わる要因を 見直すことで経済性の向上に効果がある。原料調達価格の 削減ならびに発電効率の改善は事業性の向上に大きく寄与す ることが示唆された。久保山 ${ }^{15)}$ は, 原料調達の低コスト化 方策として, 林業連携型の林地残材供給, 全木集材の拡大, 土場におけるチップ化, チッパートラックやチッパートラクター による高効率チップ生産, の 4 点を提案している。こうした 方策を進めることで, 林地残材を 7,000 [円/t-wet] 程度で 供給できるとしている。このように，高性能林業機械の導入 と収集運搬体系のシステム改善により, 地域全体における生 産体制の効率化を進めることが重要であると考えられる。ま た，原料の累積生産量が $\mathrm{n}$ 倍に増加すれば単位あたりの生 産費用が $\mathrm{n}^{\mathrm{a}}$ 倍 $(-1<\mathrm{a}<0)$ になる学習効果が現れるといわれ ている。 Junginger 26) 27) は学習曲線 28)を用いた木質燃料サ プライチェーンの分析を行っており，この中でスウェーデンに おける 1975 年から 2003 年の木質チップ等の価格の調査を おこない，累積生産量が 2 倍になるごとに，価格が 0.85 倍 になることを報告している。あくまでも，原料調達の価格は， 需要と供給のバランスにより大きく影響されるので，必ずし も原料の累積生産量が増えたからといって市場の価格が下 がるとはいえないが，累積生産量の増加による原料の伐採. 搬出・チップ化作業の効率化は図られると考えられる。他方, エネルギー効率の改善も重要である。生産するエネルギー が発電のみの場合は, 発電効率と言い換えてもよいが, 式 (2) より試算される $500 \mathrm{~kW}$ の発電効率は $9.2 \%$ あり, バ イオマス燃料のもつ発熱量のうち $9.2 \%$ し電気に変換され 


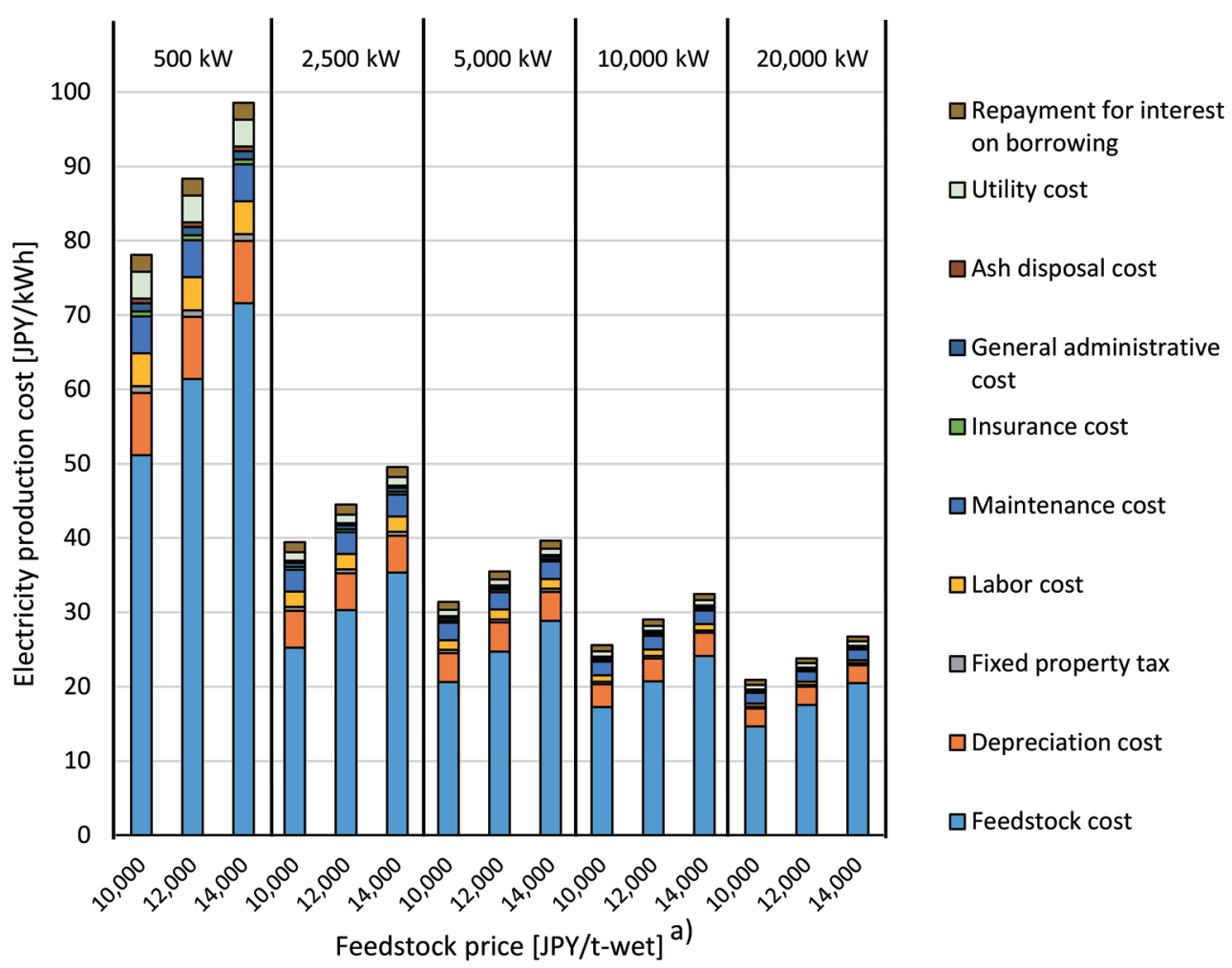

Fig. 8 Electricity production cost (Note: a) Moisture content of feedstock as 40\%)

Table 4 proportion of the breakdown of electricity generation costs

\begin{tabular}{|c|c|c|}
\hline & $\begin{array}{c}\text { Minimum } \\
\text { [\%] }\end{array}$ & $\begin{array}{c}\text { Maximum } \\
{[\%]}\end{array}$ \\
\hline Feedstock (Fuel) cost & 64.0 & 76.6 \\
\hline Depreciation cost & 8.5 & 12.6 \\
\hline Fixed property tax & 0.9 & 1.3 \\
\hline Labor cost & 1.6 & 5.7 \\
\hline Maintenance cost & 5.0 & 7.4 \\
\hline Insurance cost & 0.7 & 1.0 \\
\hline General administrative cost & 0.4 & 1.4 \\
\hline Ash disposal cost & 0.6 & 0.8 \\
\hline Utility cost & 2.2 & 4.6 \\
\hline Repayment for interest on borrowing & 2.3 & 3.4 \\
\hline
\end{tabular}

ず，残りの9割以上は熱として捨てられることを意味してい る。FIT 先進国のドイッでは，木質バイオマス発電は熱電併 給 $(\mathrm{CHP})$ が前提となっているので, 発電により併産される 排熱も利用され，エネルギーの総合効率が高いエネルギー システムが普及している。さらに，ドイツでは，水蒸気の代 わりに，水よりも低沸点で沸騰するフロン等を用いてタービン を回す ORC（Organic Rankine Cycle）発電方式が普及して おり，この方式だと発電出力が $500 \mathrm{~kW}$ 程度でも発電効率は $15 \%$ 以上と高い 15$)$ 。国内の木質バイオマス発電も, 今後は, 排熱の需要を確保し，熱電併給システムを導入したバイオマ スエネルギーの高度利用に向けた取り組みが重要である。

さて, 発電コストの内訳で然料費に次いで大きな項目は, 設備の減価償却費, 修繯費, 人件費、ユーティリティ費と
なる。減価償却費は発電規模が大きくなれば, 発電コスト 当たりの費用は小さくなる。たとえば, $5,000 \mathrm{~kW}$ のプラン 卜の減価償却費は 3.9 円 $/ \mathrm{kWh}$ であり, 20,000 kW のそれ は 2.4 円 / kWh である。ただし，規模が大きくなるにつれ て電力生産単位当たりの設備費用や修繥費は低減する一方 で，バイオマス燃料の必要量は増加 (Fig. 7) し, それに 伴って集荷圈が拡大するため輸送コストがかさむので電力生 産単位当たりの原料費は増加する。同様に，大規模になる と持続的に燃料を確保するためのリスクが増加する。バイオ マス発電の建設にあたっては，地域の資源量調査を十分に 行った上で, 設備費用の規模効果と燃料調達における輸送 コストのバランスを踏まえてプラントの最適規模を決定するこ とが重要である。

灰の処理費用の試算にあたっては, バイオマス中の灰分 率 1\% -dry wt, 灰の処理単価 20,000 円/t と仮定しているが, 発電コストに占める灰の処理費用は $1 \%$ 以下となり，相対的 に小さいことが明らかとなった。また，灰は用途開拓ができ れば無償で引き取られる可能性もある。

\section{3 感度分析}

本節では, 5.2 節での結果を踏まえて，その信頼性につい ての分析を行う。Table 5 には，それぞれの要因が変化した 場合の発電コストへの影響（要因別感度分析）について検 討した結果を示す。各要因の変動幅は, 基本ケースの值の 土20\%をした。ただし, 稼働日数のみ土 $5 \%$ とした。基本ケー スとは, 4.3 節 Fig. 8 の発電コストの試算に用いた前提条件 である。原料の含水率と発電効率の変動に対する発電コス 
Table 5 Change of cost with varying input data

\begin{tabular}{l|c|c}
\hline & Variation & $\begin{array}{c}\text { Change of cost } \\
\text { / base cost }\end{array}$ \\
\hline Moisture content of feedstock & $80-120 \%{ }^{\text {a) }}$ & $0.89-1.16$ \\
\hline Power generation efficiency & $80-120 \%$ & $0.87-1.19$ \\
\hline Auxiliary power ratio & $80-120 \%$ & $0.97-1.04$ \\
\hline Annual operation days & $95-105 \%$ & $0.98-1.02$ \\
\hline Construction cost & $80-120 \%$ & $0.95-1.05$ \\
\hline Labor cost & $80-120 \%$ & $0.99-1.01$ \\
\hline Utility cost & $80-120 \%$ & $0.99-1.01$ \\
\hline
\end{tabular}

Note: a) $100 \%$ is equal to no variation. b) Base cost is the electricity production cost as shown Fig. 8.

トへの影響は大きく，原料含水率が $40 \%$ から $48 \%$ になった 場合には発電コストは $16 \%$ 増加することが明らかとなった。 また, 発電効率が前提条件（式 (2) で試算される) よりも 20\%低下した場合には，発電コストが 19\%増加することがわ かった。それ以外の要因については, 相対的に小さく, 変 動の影響は少ないといえる。

\section{4 損益分岐点における燃料価格と発電規模の関係}

原料価格を変化させ, 各発電規模における事業収支を試 算した。その結果の一例を Fig. 9 に示す。この図の縦軸は 経営収支を発電量で除した值で $\mathrm{kWh}$ あたりの収入と支出の バランスを表している。この縦軸が 0.0 円 / $\mathrm{kWh}$ の点は, 利 益も損失も出ない点で損益分岐点という。この点に対応する 横軸の接点は原料の支払額限界点を示している。原料価格 がこの点を超えると, 経営収支は赤字となる。支払額限界 点の求め方は, 図中の関係式の切片を傾きで除した值となる。 この場合は, 13,730円/生-トンと試算される。このようにして, 発電規模と原料含水率を変化させ, 損益分岐点上にある原 料価格を算出した。Fig. 10 には, 各発電規模における損益 分岐点上の原料価格を燃料含水率の違いごとにプロットし たグラフを示す。伐採時の間伐材や, 林地残材の含水率は スギの場合 55 〜 $60 \%$ といわれているので, 発電所での燃焼 段階ではその含水率が低下し, 最大でも50\%程度から十分 に乾燥された 30 〜 $0 \%$ の木質チップが原料 (燃料) として 使用されるので，ここでは原料含水率を50\%から $20 \%$ まで の範囲について試算した。任意の発電規模と原料含水率に おける縦軸交点をみることで, 損益分岐点上の原料価格を 確認することができる。たとえば, 発電規模 5,000 kW, 原 料含水率 $30 \%$ の場合には, 損益分岐点上の原料価格は約 12,500 円/t-wetとなる。ただし, ここに示す原料価格は, 損益分岐点上のものなので, 発電所側の利益を考慮すると 実際の原料価格はこの值以下になること, さらに, この試 算には 4.3 節のばらつきがあることに注意されたい。供給側 は森林からの木質バイオマスの搬出・チップ化コストの目標 值を, 最低でも損益分岐点上の燃料調達価格以下に設定す る必要がある。木質バイオマス発電の持続的な運営と林業 の活性化のために, FIT を上手く活用しバイオマスの供給側,

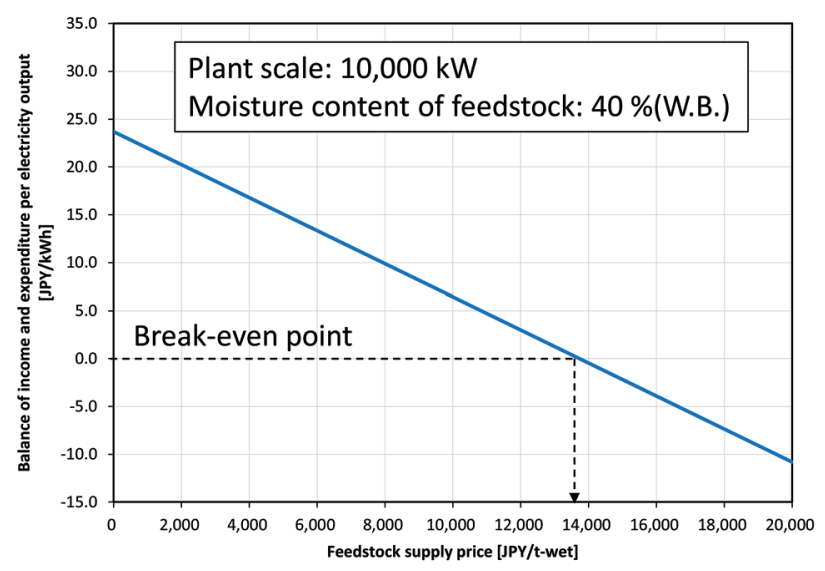

Fig. 9 Relationship between the balance of income and expenditure and feedstock supply price

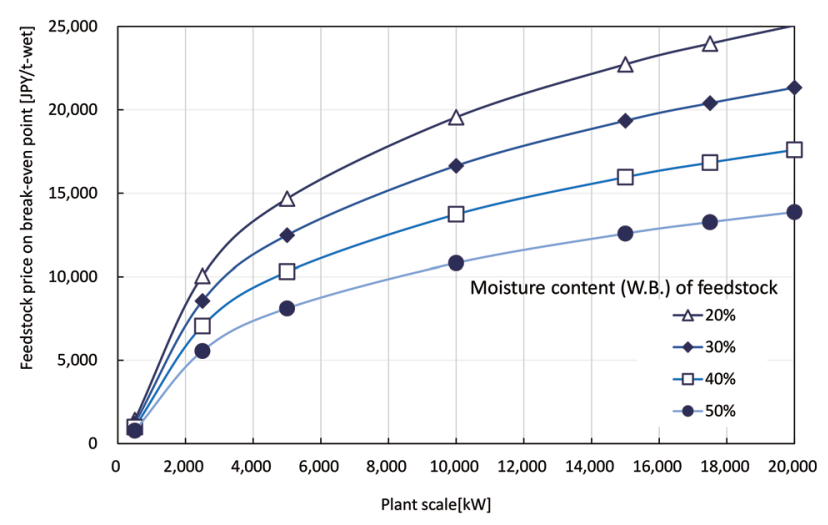

Fig. 10 Relationship between feedstock supply price on the break-even point and plant scale of the biomass power generation under FIT program

需要側が連携して双方に経済的な利益が生まれるポイントを 見いだしていくことが重要である。

\section{6. おわりに}

本研究は, 未利用木質バイオマスを燃料とした発電事業 において，原料供給コストの目標設定に資する情報を提供す ることを目的とし, 発電コストと原料価格に関する関係性を 明らかとした。まず，木質バイオマス発電のコスト試算モデ ルを作成し, $500 \mathrm{~kW} \sim 20,000 \mathrm{~kW}$ 規模の発電事業に関す る検討を行った。発電コストに占める各要素の割合を定量 的に示し，原料コストが6 割以上であることを明らかにした。 さらに, コスト試算に関する精度について感度分析を実施し, その結果を踏まえた上で, 各発電規模における事業の損益 分岐点上にある原料価格を明らかにした。森林の未利用バ イオマスの供給コストに関する限界の指標の一つを提示でき たと考える。バイオマス発電の基本は, 総合効率の高い熱 電併給システムを地域に分散させることであると考えられる ので，今後は熱の利用に関する議論が必要であると考える。 


\section{謝 辞}

本研究の遂行にあたり, 森林総合研究所の多くの関係者 に大変有意義なご意見を頂いた。また，本研究は，森林総 合研究所運営交付金プロジェクト（D1P06 木質バイオマスエ ネルギー事業支援システムの開発）の一環として行われた。 ここに記して謝意を表する。

\section{文 献: References}

1) Agency for natural resources and Energy, Ministry of Economy, Trade and Industry, http://www.enecho.meti. go.jp/category/saving_and_new/saiene/kaitori/kakaku. html (Last acccess: 2014.6.23)：経済産業省資源エネル ギー庁, http://www.enecho.meti.go.jp/category/saving_ and_new/saiene/kaitori/kakaku.html (Last acccess: 2014.6.23)

2) Ando, N., Norin Kinyuu, 67(1), 2-16(2004) : 安藤範親, 農林 金融, 67(1), 2-16 (2004)

3) Committee of the price estimation, Ministry of Economiy, Trade and Industry, http://www.meti.go.jp/ committee/chotatsu_kakaku/pdf/report_003_01_00. pdf (Last acccess: 2014.6.23)：調達価格等算定委員会, 経 済産業省, http://www.meti.go.jp/committee/chotatsu_ kakaku/pdf/report_003_01_00.pdf (Last acccess: 2014.6.23)

4) E-Contecture The May issue 2014, NIPPO CO., LTD., p.16 (2014) : イー・コンテクチャー 2014 年 5 月号, 日報ビ ジネス株式会社, p.16 (2014)

5) Mokuzai Kenzai Weekly (magazine for Building Materials) No. 1978, Japan forest products journal co. ltd., (2014):木材建材ウイクリーNo.1978, 日刊木材新聞社, (2014)

6) Forestry agency, Ministry of agriculture, Forestry and Fisheries, http://www.rinya.maff.go.jp/j/riyou/biomass/ hatudenriyou_guideline.html (Last acccess: 2014.6.23) : 林野庁, http://www.rinya.maff.go.jp/j/riyou/biomass/ hatudenriyou_guideline.html

7) Mokuzai Kenzai Weekly (magazine for Building Materials) No. 1971, Japan forest products journal co., ltd., (2014):木材建材ウイクリー No.1971, 日刊木材新聞社, (2014)

8) Dornburg, V.; Faaij, A. P. C., Biomass Bioenerg., 21, 91-108 (2001)

9) Hara, T.; Shinguu, H.; Katada, M.; Yoshikawa, K.; Min, T.; Namioka, T.; Matsubara, H., J. Jpn. Inst. Energy, 83, 815820 (2004) : 原勉, 新宮宏昭, 片田正弘, 吉川邦夫, ミン テジン, 波岡知昭, 松原弘直, 日エネ誌, 83, 815-820 (2004)

10) Kubo, K.; Nakata, T., J. Jpn. Inst. Energy, 83, 1013-1020 (2004): 久保一雄, 中田俊彦, 日工亦誌,83, 1013-1020 (2004)

11) Caputo, A. C.; Palumbo, M.; Pelagagge, P. M.; Scacchia, F., Biomass Bioenerg., 28, 35-51 (2005)
12) Kurihara, S.; Uto, R.; Aoki, Y., J. Jpn. Inst. Energy, 88, 310325 (2009) : 栗原史郎, 宇都隆一, 青木頼幸, 日工ネ誌, 88, 310-325 (2009)

13) Kamimura, K.; Kuboyama, H.; Yamamoto, K., J. Jpn. Inst. Energy, 88, 877-883 (2009) : 上村佳奈, 久保山裕史, 山本 幸一, 日工衣誌, 88, 877-883 (2009)

14) Taniguchi, M.; Tanaka, H.; Ito, Y.; Nishiyama, A.; Sasauchi, K., J. Jpn. Inst. Energy, 88, 906-911 (2009) : 谷口 美希, 田中秀直, 伊藤嘉文, 西山明雄, 笹内謙一, 日工市誌, 88, 906-911 (2009)

15) Kuboyama, H., in Outlook study on the forest, forestry and forest industry: Data, theory and simulation, Forestry and forest Products Research Institute, Ed., Japan Forestry Investigation Committee, pp. 73-95 (2012) : 久保山裕史, 改訂 森林・林業・木材産業の将来 予測一データ・理論・シミュレーション一, 森林総合研究 所編，日本林業調査会，pp. 73-95 (2012)

16) Matsumura, Y., in Biomass Handbook, led, The Japan Institute of Energy, Ed., Ohm-sha, p. 362 (2002) : 松村幸 彦，バイオマスハンドブック(第1版)，日本エネルギー学 会編，オーム社，p. 362 (2002)

17) Kojima, A.; Takahama, H.; Ashizawa, M., CRIEPI Research Rep. No. M07002, http://criepi.denken.or.jp/ jp/kenkikaku/report/detail/M07002.html (Last access: 2014.06.23)：小島明弘，高濱均，芦澤正美，電力中央 研究所 研究報告 M07002, http://criepi.denken.or.jp/jp/ kenkikaku/report/detail/M07002.html (Last access: 2014.06.23)

18) Kamikawa, K., Mokuzai Jouhou (Nov. 2013) 270, $1-5$ (2013): 上河潔, 木材情報 (2013 年 11 月号), 270, 1-5 (2013)

19) Sumitomo Corporation, http://www.sumitomocorp. co.jp/news/detail/id=27923 (Last access: 2014.08.08) : 住 友商事, http://www.sumitomocorp.co.jp/news/detail/ id=27923 (Last access: 2014.08.08)

20) National policy unit, Cabinet secretary, http://www. cas.go.jp/jp/seisaku/npu/policy09/archive02_shisan_ sheet.html (Last access: 2014.6.23)：内閣官房国家戦略室 コスト等検証委員会, http://www.cas.go.jp/jp/seisaku/ npu/policy09/archive02_shisan_sheet.html (Last access: 2014.6.23)

21) The Japan Institute of Energy Ed, Report of fundamental research on promotion of new energy introduction- Utilization and promotion of biomass energy conversion technology, p. 210 (2002) : 日本エネル ギー学会編，平成 13 年度 新エネルギー等導入促進基礎 調査 (バイオマスエネルギーの利用・普及政策に関する調 査), p. 210 (2002)

22) Forestry and forest Products Research Institute, Ed., Wood Industry Handbook, 4ed, Maruzen, p. 113 (2004) : 森林総合研究所監修，木材工業ハンドブック改訂 4 版，丸 
善, p. 113 (2004)

23) Wood supply and demand report, http://www.maff. go.jp/j/tokei/kouhyou/mokuzai_zyukyu/ (Last access: 2014.8.8): 平成 25 年木材需給報告書, http://www.maff. go.jp/j/tokei/kouhyou/mokuzai_zyukyu/ (Last access: 2014. 8.8)

24) Kamimura, K.; Kuboyama, H.; Yamamoto, K., Biomass Bioenerg., 36, 107-115 (2012)

25) Woody Biomass Power Generation Exploratory Committee, http://www.pref.niigata.1g.jp/ rinsei/1356765077247.html (Last access: 2014.07.01) : 木 質バイオマス発電等検討委員会, http://www.pref.niigata. lg.jp/rinsei/1356765077247.html (Last access: 2014.07.01)

26) Junginger, H. M., Doctoral Thesis of Utrecht University 2005, http://dspace.library.uu.nl/handle/1874/7123 (Last access: 2014.6.23)

27) Björheden, R., Biomass Bioenerg, 30, 289-295 (2006)

28) Asano, K., CRIEPI Research Rep. No. Y09020, http:// criepi.denken.or.jp/jp/kenkikaku/report/detail/Y09020. html (Last access: 2014.06.23) : 朝野賢司, 電力中央研 究所研究報告 Y09020, http://criepi.denken.or.jp/jp/ kenkikaku/report/detail/Y09020.html (Last access: 2014.06.23) 